AEC-NASA Tech Briefs announce new technology derived from the research and development program of the U.S. AEC or from AEC-NASA interagency efforts. They are issued to encourage commercial application. Tech Briefs are available on a subscription basis from the National Technical Information Service, Springfield, Virginia 22151. Requests for individual copies or questions relating to the Tech Brief program may be directed to the Technology Utilization Office, NASA, Code KT, Washington, D.C. 20546.

\title{
Sonic Limitations and Startup Problems of Heat Pipes
}

A heat pipe is a thermal conductance device capable of high heat transfer rates with essentially isothermal operation. The operating characteristics of a pipe with a given geometry may vary from excellent to nonfunctional; axial temperature drops of several hundred degrees have occurred in some cases.

The performance of a heat pipe depends on the type of wick, working fluid, and the external conditions imposed on it. The dynamics of the fluid flow are very complicated. Under certain operational conditions the vapor flow may be molecular or continuum, compressible or incompressible; vapor velocities may be sonic or supersonic; countercurrent flow of vapor and liquid, with communication between flow paths, may result. In designing heat pipes for high heat transfer rates these factors must be taken into account.

A series of tests has been conducted to determine the effects of sonic vapor velocities on the operational and startup characteristics of heat pipes. It was found that the introduction of small amounts of inert, noncombustible gas aids startup in certain types of heat pipes. Also, when the heat pipe is closely coupled to the heat sink, the startup system must be designed to bring the heat sink on-line slowly.

\section{Notes:}

1. The following documentation may be obtained from: National Technical Information Service Springfield, Virginia 22151 Single document price: $\$ 3.00$ (or microfiche $\$ 0.95$ )
Reference: LA-4518 (N71.18944), Sonic Limitations and Startup Problems of Heat Pipes

2. Technical questions may be directed to:

Mr. Glenn K. Ellis

Technology Utilization Officer

Office of Information Services

U.S. Atomic Energy Commission

Washington, D.C. 20545

Reference: TSP72-10368

\section{Patent status:}

Inquiries concerning rights for commerical use of this information may be made to:

Mr. George H. Lee, Chief

Chicago Patent Group

U.S. A tomic Energy Commission

Chicago Operations Office

9800 South Cass Avenue

Argonne, Illinois 60439

Source: J.E. Deverall, J.E. Kemme and

L.W. Florschuetz

Los Alamos Scientific Laboratory

under contract to

Atomic Energy Commission

(AEC-10036)

Category 03
This document was prepared under the sponsorship of the Atomic Energy Commission and/or the National Aeronautics and Space Administration. Neither the United States Government nor any person acting on behalf of the United States Government assumes any liability resulting from the use of the information contained in this document, or warrants that the use of any information, apparatus, method, or process disclosed in this document may not infringe privately owned rights. 